\title{
GROUPING OF REGIONS OF UKRAINE IS AFTER LEVEL OF ECONOMIC ACTIVITY OF INDUSTRY
}

\begin{abstract}
Grouping of regions of Ukraine is conducted by value integral indexes of economic activity of their industry. In accordance with certain gradation, for most areas (20 in 2015 against 23th in 2014) characteristic was a subzero value of economic activity, caused by the negative values of financial result from ordinary activity to taxation.

Drawn conclusion, that one of reasons of unprofitableness of domestic industry there is an excessive volume of other (unconnected with basic activity) charges. For more detailed study of this situation necessary is working out in detail of these charges in the financial reporting of enterprises.

For the increase of economic activity of industry of regions, creation of educational-scientifically-productive centers of branch and regional aspiration offers. The aim of functioning of such centers is an increase of level of qualification of workers and innovative constituent of technological development of industries and regional economies in accordance with the necessities of market that will assist the increase of volume of hi-tech products and in a result - positive dynamics of economic potential (assets) and financial results of industry of regions.
\end{abstract}

(C) Lyubomir Sozanskyy, 2017.

Sozanskyy Lyubomir, Cand. of Economic Sciences, Institute of Regional Studies named after M. I. Dolishnyi, National Academy of Sciences, Lviv, Ukraine. 


\section{Key words:}

Integral estimation, economic activity, industry of regions of Ukraine, growth of financial result rate to taxation.

JEL: L1, L52.

Important pre-condition of economic and social development of country is competitive industry, as a key link of economy that co-operates and has an influence on most segments of the social, financial and economic systems of country. In particular the state, tendencies and results of functioning of industry, is represented on development of building industry, domestic and external trade, create pre-conditions for development of service business and other.

However a modern model of home economy is raw material and dependency upon an import with predominance of subzero technology of productions with a not high value added that brakes development of industrial potential of country.

The problem aspects of development of domestic industry are represented in labours . Amosha, O. I., Vyshnevskyy, V. P. (Ed.), Zbarazska, L. O., Kindzersky, Y. V. Heyets, V. M., \& Ostashko, T.O., Shynkaruk, L. V., Bevz, I. A., Baranovska, I. V., Ishchuk, S. O.

The estimation of influence of free trade Zone between Ukraine and countries-members of $€ C$ on the industrial types of activity is carried out by the group of scientists under the direction of academician NAS of Ukraine Heyets, V. M. (Heyets, V. M., \& Ostashko, T.O. (Eds.) (2016)).

Contradictions of forming of pattern of production and internal market in Ukraine are reflected in (Shynkaruk, L. V. (Ed.), Bevz, I. A., Baranovska, I. V., \& et. al. (2015)). Complex description of features of development of national industry is driven to (Amosha, O. I., Vyshnevskyy, V. P. (Ed.), Zbarazska, L. O., \& et. al. (2014)). Principles of strategy and politics of the state in development of industry are reflected in (Kindzersky, Y. V. (2013)). The basic methods of increase of profit of industrial enterprises and design of prognosis of operating profit on the basis of effect of productive lever offer in (Ishchuk, S. O. (2009)). 
Key tendencies, results and prospects of development of industry of the Lviv area, are reflected in (Ishchuk, S. O. (2014)).

Without regard to the presence of sound researches of problem of industry of Ukraine, actual is a study of economic activity of industry in regional and interregional aspects that will assist perfection of the programs and strategies of development of industry of regions of country.

The aim of the article is an estimation of economic activity of industry of regions of Ukraine and forming of suggestions in relation to her increase.

The estimation of economic activity of industry of regions of Ukraine is carried out after such stages. On the first primary indexes are counted, that in totality represent economic activity of industry of regions of Ukraine.

In accordance with ${ }^{1}$ methodology of integral evaluation of competitiveness industrial to the sector of economy of regions of Ukraine. (worked out by the department of development of productive sphere of region and investments of $\mathrm{SI}$ «Institute of Regional Research n. a. M. I. Dolishniy of the NAS of Ukraine» under direction of Ishchuk, S. O. and within the framework of implementation of budgetary theme the "Component increases of competitiveness of industry of the Western region of Ukraine in the conditions of free trade between Ukraine and ES»)economic activity of industry is characterized by two key indexes: growth of assets rate and growth of financial result rate from ordinary activity to taxation.

On the second stage the integral indexes of economic activity of industry of regions are certain by setting of norms of values of the primary indexes counted on the first stage, and their further integration after middle arithmetic. Setting of norms of indexes comes true according to the Methodology of calculation of integral regional indexes of economic development, ratified by the order of the State committee of statistics of Ukraine from 15.04.2003 № 114 (Methods of calculation of integral index of regional economic development, approved by the Law of the State Statistics Committee of Ukraine of 15.04.2003 № 114).

On the third stage, grouping of regions of Ukraine is carried out after the level of economic activity of their industry. The criterion of differentiation of areas is a range of values of the integral indexes counted on the second stage: the first group is areas with the high level of economic activity (the value of index of economic activity presents $0,67-1,00)$; second group - with the middle level of economic activity $(0,33-0,67)$; third group - with the low level of economic activity $(0,00-0,33)$.

\footnotetext{
${ }^{1}$ An author of the article is a coauthor of methodology of integral evaluation of competitiveness industrial to the sector of economy of regions of Ukraine (worked out by the department of development of productive sphere of region and investments of $\mathrm{SI}$ «Institute of Regional Research n. a. M. I. Dolishniy of the NAS of Ukraine »under the direction of Ishchuk, S. O. and within the framework of implementation of budgetary theme the "Component increases of competitiveness of industry of the Western region of Ukraine in the conditions of free trade between Ukraine and ES»).
} 
As a result of study undertaken an after these stages such analytical information and estimation are got.

Qualificatory influence on the change of level of economic activity of industrial sector of economy of Ukraine during 2011-2015 had first from the adopted indexes. Yes, in 2014 the enormous falling of financial result took place from ordinary activity to taxation of industry - to the level of loss in a sum a 166414 million hrn. against a profit (13 698,3 million hrn.) in 2013 (rice. 1a). Accordingly a growth of financial result rate from ordinary activity to taxation presented -1314 , $9 \%$. In 2015, comparatively with 2014th, the value of this index diminished to $9,0 \%$, and in absolute expression the loss of industry made a 181361 million hrn.

The index of growth of assets rate had considerably less influence on the change of level of economic activity of industry in Ukraine: his value in 20112013 diminished on 9,8 percent points, and in next two years, opposite, increased on 10,5 (figure 1b). The last tendency can be the sign of increase of capital of domestic industry in a cost equivalent.

By integration of values of indexes of growth of financial result rate from ordinary activity to taxation and growth of assets rate the indexes of economic activity of industry are expected, on the basis of values of that grouping of regions of Ukraine (table 1) is conducted.

In accordance with certain gradation, for swinging majority of areas (20 in 2015 against 23th in 2014) there is a characteristic low level of economic activity.

In 2014-2015 of high level of economic activity of industry it was not attained in none of areas. During 2011-2013 amount of areas industry of that would answer such level of economic activity, tendentious diminished: from 5 in 2011 - to one in 2013.

To the group of middle level of economic activity of industry 2015 was entered by four areas (Volyn, Vinnytsya, Chernivtsi and Kharkiv), basic activity of industrial sector of economy of that in this year was profitable. First three from them attained the greatest among the areas of Ukraine values of index of growth of financial result rate from ordinary activity to taxation (to the profit) (from 1,511 in Chernivtsi - to 2,373 in Volyn), and also mean values of growth of assets (from 0,229 in Volyn - to 0,378 in Vinnytsya) (table 2) .

For industry of the Kharkiv area characteristic was a negative $(-0,27)$ growth of financial result rate from ordinary activity to taxation (a profit diminished to 602 million hrn. against a 618,7 million hrn. in 2014) and middle growth of assets $(0,152)$ rate. It costs to mark that the Kharkiv area - only in Ukraine, activity of industry of that was profitable in throughout the year of analyzable period.

Part of areas of the second group in the structure of regions of Ukraine on the volume of assets of industry in 2015 totally presented $7,94 \%$, from them 4 , $74 \%$ were on the Kharkiv area (table 3 ). 
Vol. 16. № 1 (60). January-March 2017

ISSN 2519-4070

Figure 1

\section{Indexes of economic activity of industry of Ukraine}

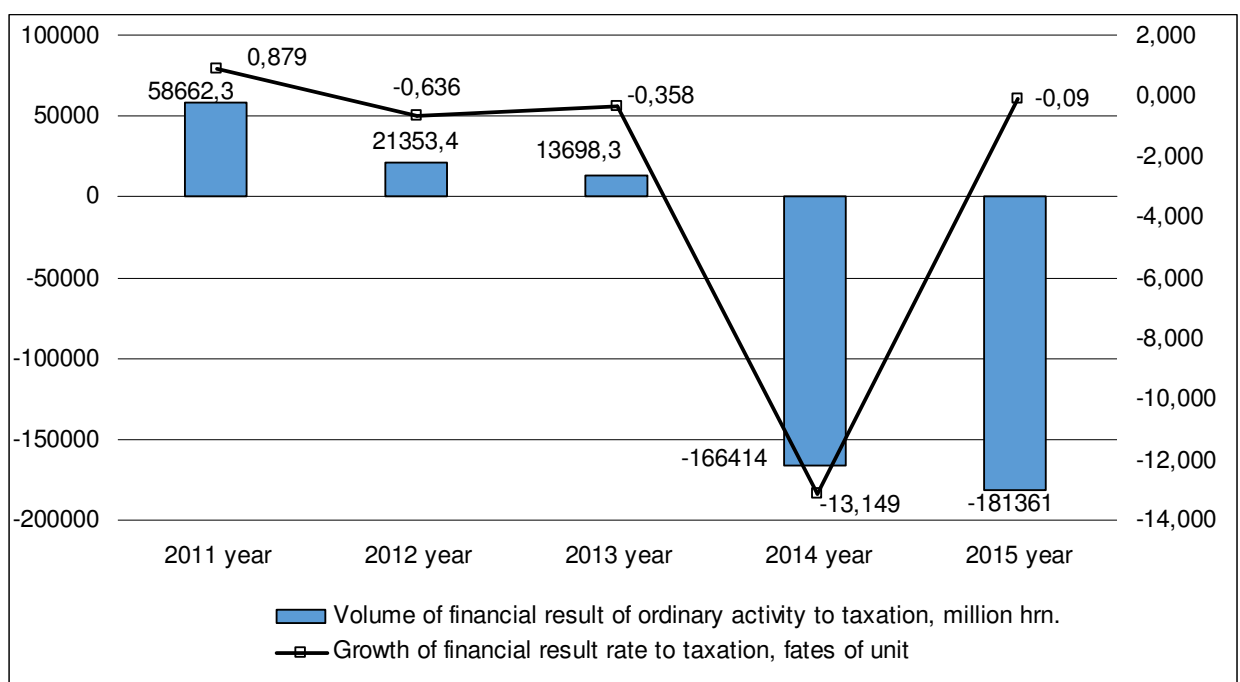

a)

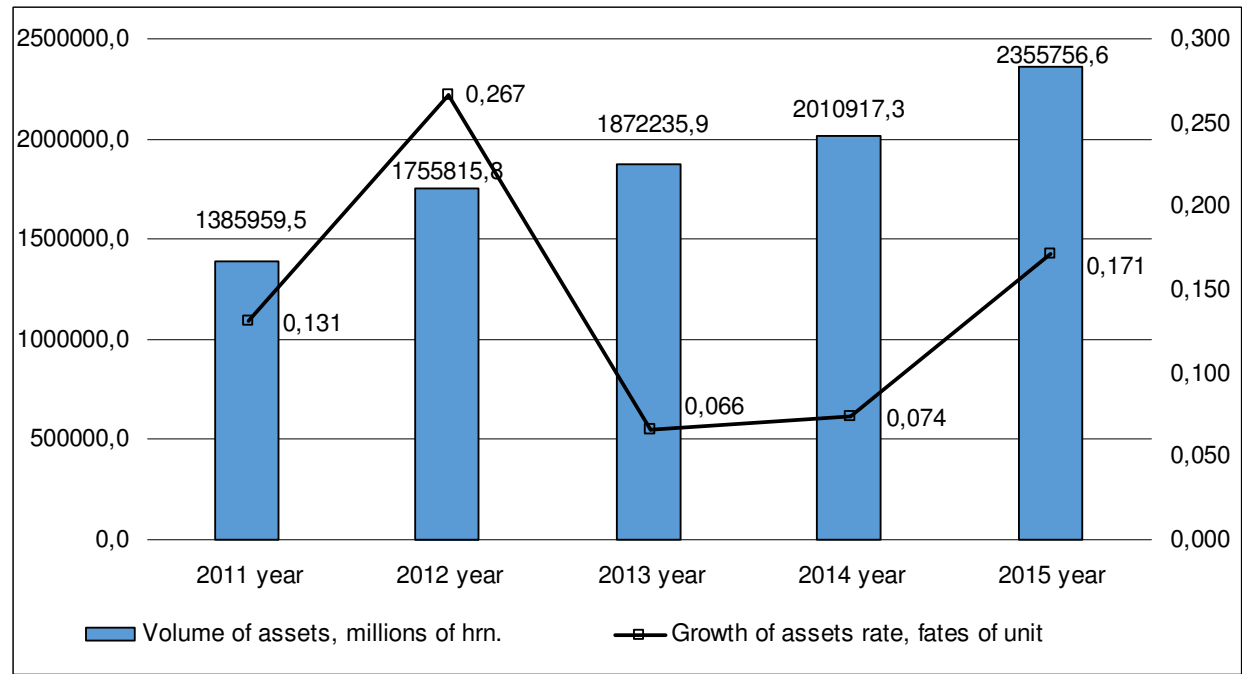

b)

Source: it is built after (State Statistics Service of Ukraine (2016) 


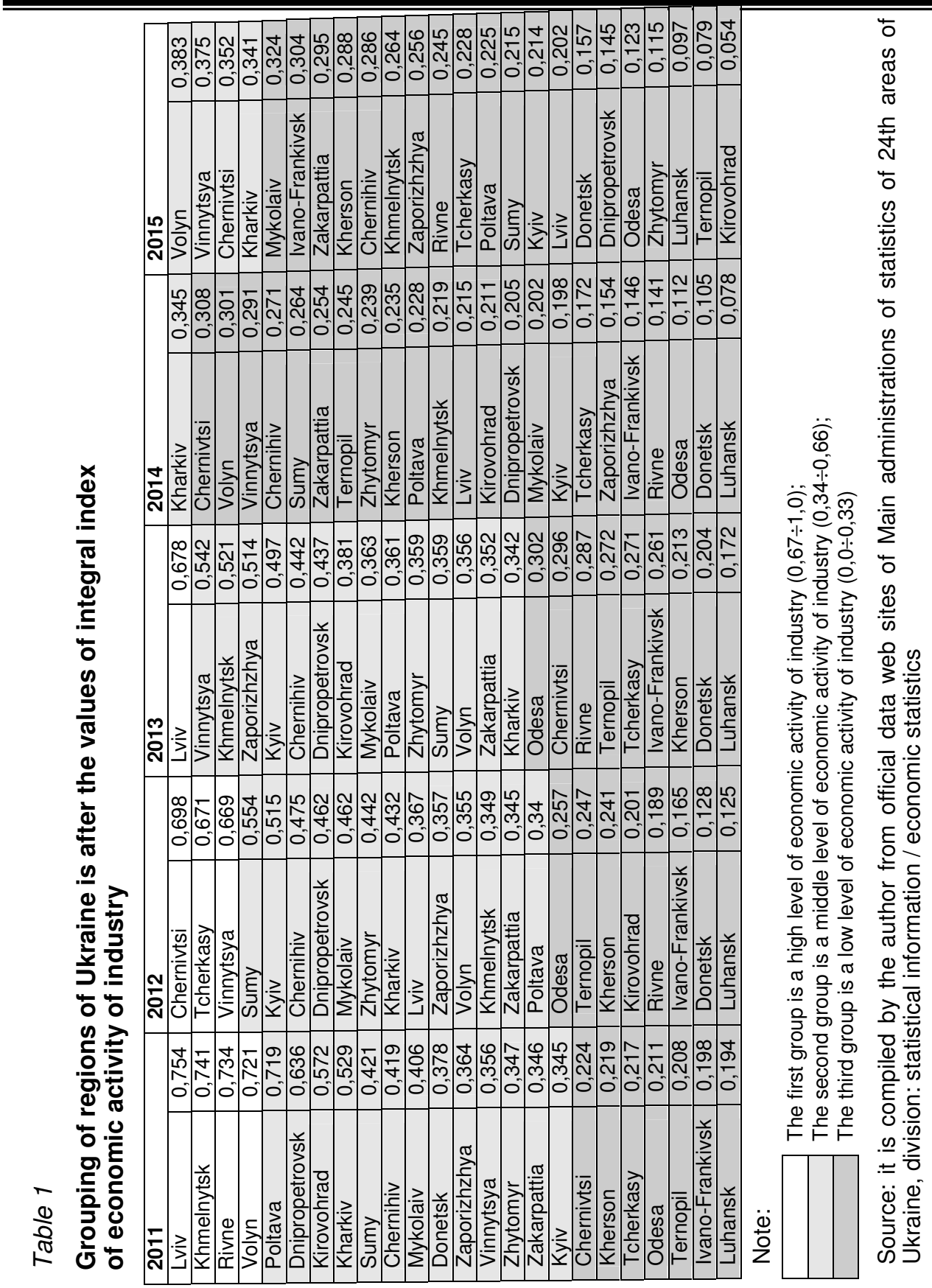




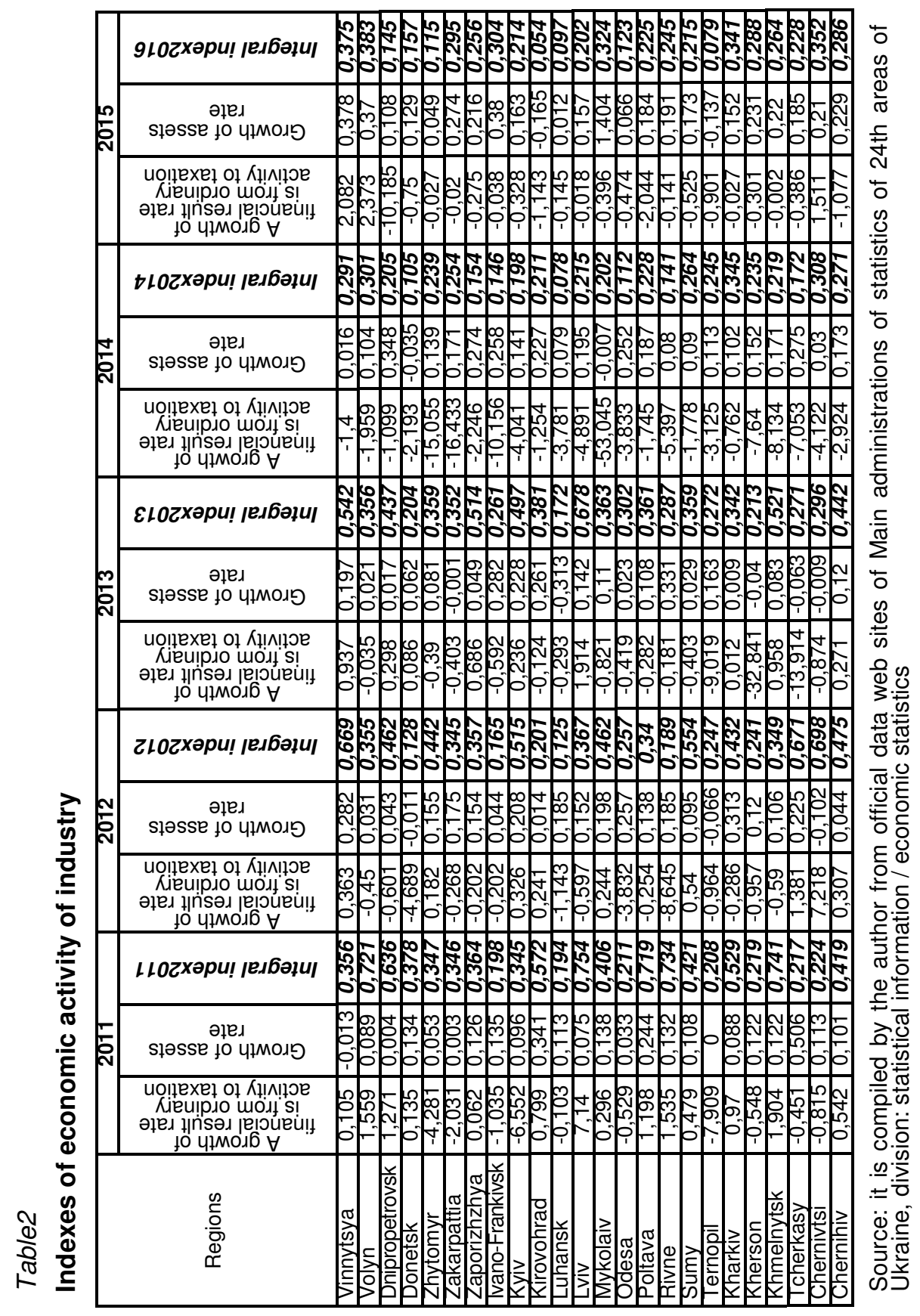




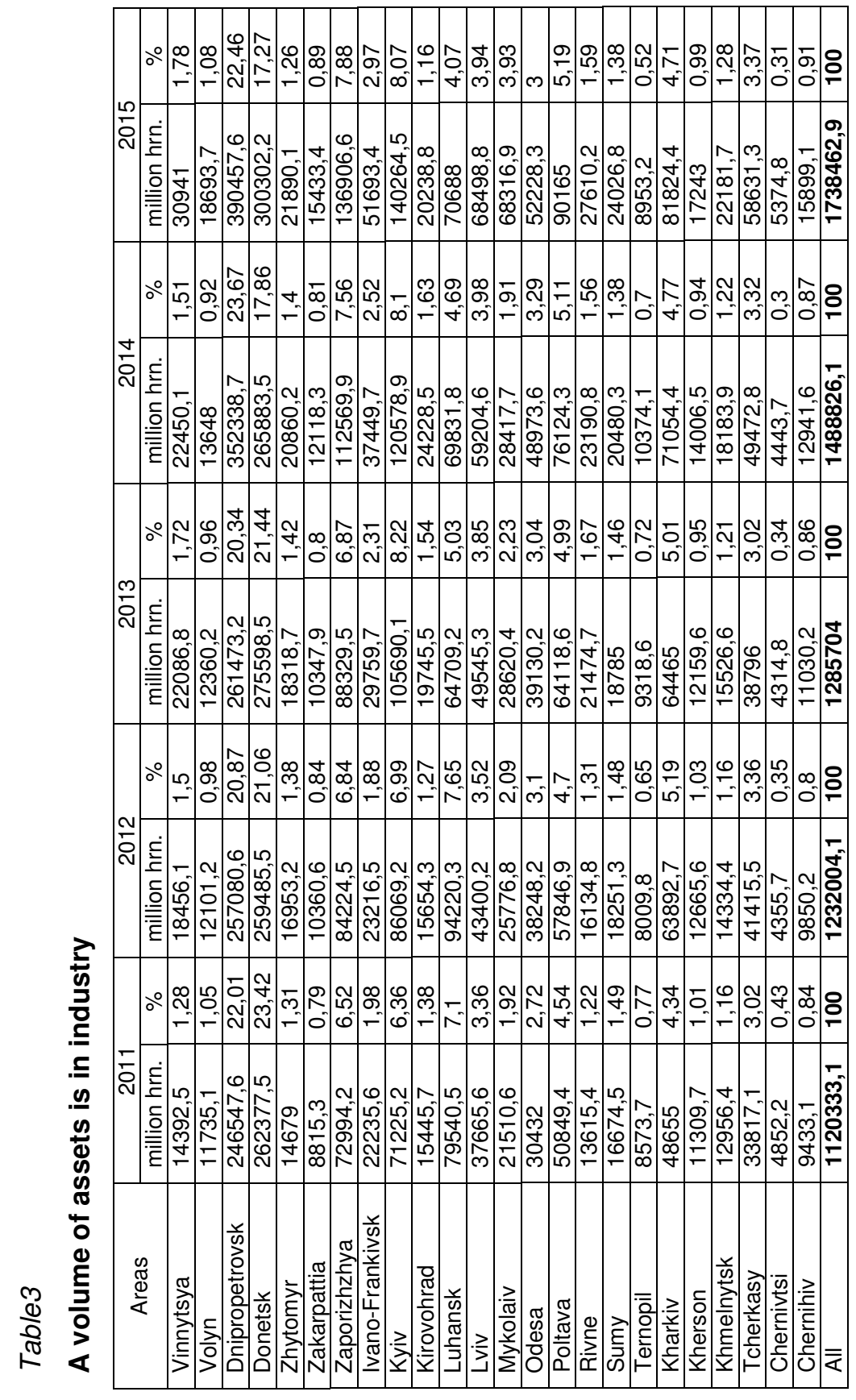

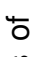
$\stackrel{\frac{1}{2}}{\mathscr{0}}$ 亳

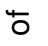
(n) $\stackrel{0}{.0}$ $\frac{\pi}{\infty}$ ¿ 응 을 
The third group in 2015 was formed by twenty areas with the low level of economic activity of industry, caused by the negative values of financial result from ordinary activity to taxation. The leader of this group was the Mykolaiv area, as her industry attained the greatest among the regions of Ukraine value of growth of assets $(1,404)$ rate. The value of index of growth of financial result (to the loss) of industry of this area rate presented at the same time -0,396.Other areas of the third group can be conditionally divided into three sub-groups.

The first sub-group is twelve areas (Zakarpattia, Zaporizhzhya, Kyiv, Lviv, Ivano-Frankivsk, Poltava, Rivne, Sumy, Kherson, Khmelnytsk, Tcherkasy and Chernihiv) with the mean values of index of growth of assets (from 0,157 in Lviv - to 0,380 in Ivano-Frankivsk) rate. Values of index of growth of financial result (to the loss) rate from ordinary activity to taxation of industry of these areas were in a range from - 0,002 (in Khmelnitsky) to - 2,044 (in Poltava).

To the second sub-group five areas (Dnepropetrovsk, Donetsk, Zhytomyr, Luhansk and Odesa) are attributed with the subzero values of index of growth of assets (from 0,012 in Luhansk - to 0,129 in Donetsk) rate. The values of index of growth of financial result (to the loss) rate from ordinary activity to taxation of industry of these areas varied from - 10,185 (in Dnepropetrovsk) to - 0,027 (in Zhytomyr).

The third sub-group is the Kirovohrad and Ternopil areas with negative the value of indexes of both growth of assets $(-0,165$ and $-0,137$ accordingly) rate and growth of financial result (to the loss) $(-1,143$ and $-0,901)$.

Part of areas of the third group in the structure of regions of Ukraine on the volume of assets of industry in 2015 totally laid down $92,06 \%$, from them $22,64 \%$ was on Dnipropetrovsk, $17,41 \%$ - on Donetsk, $8,13 \%$ - on Kyiv.

Summarizing, it is possible to assert that in 2015, comparatively with 2014th, in Ukraine the revival of economic activity of industry, the basic signs of that in the cut of regions were began:

- proceeding in profitability of ordinary activity is to taxation of industrial sector of economy of the Volyn, Vinnytsya and Chernivtsi areas;

- reduction of negative values of index of growth of financial result rate from ordinary activity to taxation of industry in 18 areas, from that most in Mykolaiv, Zakarpattia, Zhytomyr, Ivano-Frankivsk;

- an increase of values of index of growth of assets of industry rate is in 14 areas, from that most in Mykolaiv, Vinnytsya, Volyn and Chernivtsi.

At the same time the signs of braking of economic activity of industry in Ukraine in 2015 were: 
- further increase of volume of loss from ordinary activity to taxation of industry in 9 areas, from that most in Donetsk, Dnepropetrovsk, Luhansk and Kirovohrad;

- increase of negative values of index of growth of financial result rate from ordinary activity to taxation of industry in the Dnepropetrovsk and Poltava areas;

- -reduction of volume of profit is from ordinary activity to taxation of industry of the Kharkiv area;

- reduction of values of index of growth of assets in 10 areas, from that in Kirovohrad and Ternopil, rate - to negative.

Thus, on the basis of results of analysis it is possible to establish the increase of economic activity of industry in the Vinnytsya, Volyn and Chernivtsi areas, and also her revival in most central and western areas of Ukraine (To Mykolaiv, Zakarpattia, Zhytomyr, Khmelnytsk, Rivne, Lviv). At the same time in 2015 the decline of level of economic activity of industry took place in the Dnepropetrovsk, Poltava, Sumy and Odesa areas.

On results research certainly, that the basic problem of domestic industry is subzero efficiency of financially-economic activity. Yes, during 2014-2015 a financial result from ordinary activity to taxation of industry of Ukraine was negative (a loss presented, accordingly, 166414 and 181361 million hrn.). But financial result (profit) from an operating-room, id est. basic (or productive) activity laid down, accordingly, 26 645,9 and 18387,9 million hrn. The same situation (large a difference between the result of operating activity and financial result to taxation was observed in industry of most areas of Ukraine.

Thus, reason of unprofitableness of domestic industry is an excessive volume of other (unconnected with basic activity) charges. To these charges take:

- financial charges - show charges on percents and other charges of enterprise, related to borrowing;

- losses from participating in a capital - represent a loss from investments in the associated or general companies associated, the account of that is conducted by the method of participating in a capital;

- other charges - fix the prime price of realization of financial investments; losses are from unoperating exchange rate differences; losses are from decline of financial investments and inconvertible assets; charges of enterprises are from the change of book value of financial instruments that is estimated on a fair value; other charges that arise up during economic activity (except financial charges), but unconnected with operating activity enterprises). 
Taking into account opaque maintenance of swinging majority of items of these expenses (and too "other»), there is a necessity of their working out in detail for the financial statements of enterprises with the aim of an increase control from the side of Government fiscal service of Ukraine after them.

Taking into account that in 2015 industry of swinging majority of areas was unprofitable, there was an increase of loss in 9 areas, and in 10 - reduction to the growth of assets rate expedient is perfection of organizationally-economic mechanisms of stimulation of development of industry of all regions by the increase of investment attractiveness of industrial sector of economy, conditioning for the decision of problems of skilledness of workers, material motivation, and also modernization of productive resources.

To the increase of skilledness of workers, and thus to the potential increase of volume of hi-tech products with a high value added and in a result renewal to economic potential and profitability of industry creation will assist and organization of activity of educational-scientifically-productive centers of branch and regional aspiration (ESPCBR). An aim of functioning of such centers is an increase of level of qualification of workers and innovative constituent of technological development of industries and regional economies in accordance with the necessities of market. ESPCBR can function on the material and technical bases of productive enterprises and educational establishments on condition of their modernization or accordance to the necessities of modern production. Studies must come true after the programs worked out because of collaboration of scientists and practical workers and to answer strategies of regional development. Interest in functioning of ESPCBR can arise up at such parties:

- productive enterprises - for in-plant training of workers with the aim of mastering of technological novelties and introduction of innovations (new kinds and standards of products or services), modernization of productive processes, increase of the labour productivity;

- educational establishments - for strengthening of practical constituent of educational process (qualities of productive practices);

- scientific establishments - for strengthening of the informative and material and technical providing of scientific developments, inventions and innovations and their tests and introductions;

- regional state administrations - for providing social economic development of regions.

For the expert participating foreign practices and scientists can be attracted in functioning of centers, and for adjusting of external and internal connections are regional state administrations. Sourcings of ESPCBR : central and local budgets, money of educational and productive enterprises and associations, receipt from realization of inventions, developments and services et al. 
Thus, the prospect of further researches is at the search of methods of removal of unprofitableness of subjects of industrial activity and development of directions of development of industry of regions.

\section{References}

1. Amosha, O. I., Vyshnevskyy, V. P. (Ed.), Zbarazska, L. O., \& et. al. (2014). Promyslovist' i promyslova polityka Ukrayiny 2013: aktual'ni trendy, vyklyky, mozhlyvosti [Industry and industrial policy of Ukraine 2013: current trends, challenges, opportunities] (Analytical report). Donetsk: Institute of the Economy of Industry of the NAS of Ukraine [In Ukrainian].

2. Kindzersky, Y. V. (2013). Promyslovist' Ukrayiny: stratehiya i polityka strukturno-tekhnolohichnoyi modernizatsiyi [Ukraine industry: strategy and policy of structural and technological modernization]. Kyiv: Institute for Economics and Forecasting NAS of Ukraine [In Ukrainian].

3. Heyets, V. M., \& Ostashko, T.O. (Eds.) (2016). Implementatsiya Uhody pro asotsiatsiyu mizh Ukrayinoyu ta ES: ekonomichni vyklyky ta novi mozhlyvosti [The implementation of the Agreement about Association between Ukraine and the EU: Economic Challenges and opportunities] (Scientific report). Kyiv: Institute for Economics and Forecasting NAS of Ukraine [In Ukrainian].

4. Shynkaruk, L. V. (Ed.), Bevz, I. A., Baranovska, I. V., \& et. al. (2015). Strukturni transformatsiyi v ekonomitsi Ukrayiny: dynamika, superechnosti ta vplyv na ekonomichnyy rozvytok [The structural transformations in the economy of Ukraine: dynamics, contradictions and impact on economic development] (Scientific report). Kyiv: Institute for Economics and Forecasting NAS of Ukraine [In Ukrainian].

5. Ishchuk, S. O. (2009). Model' rozrakhunku operatsiynoho prybutku promyslovykh pidpryyemstv [Model of calculation of operating profit for industrial enterprises]. Ekonomika i prohnozuvannya - Economics and Forecasting. 3, 134-143 [In Ukrainian].

6. Ishchuk, S.O. (2014). Promyslovist' L'vivs'koyi oblasti: klyuchovi tendentsiyi ta perspektyvy rozvytku [Industry of Lviv region: key trends and of developments prospects]. Sotsial'no-ekonomichni problemy suchasnoho periodu Ukrayiny [Socio-economic problems of the modern period Ukraine]. Issue 3 (107). Regional policy in Ukraine: current situation and ways to accelerate. (pp. 275-284). Lviv: Institute of Regional Research of the NAS of Ukraine [In Ukrainian].

7. Metodyka rozrakhunku intehralnykh rehionalnykh indeksiv ekonomichnoho rozvytku, zatverdzhena Nakazom Derzhavnoho komitetu statystyky Ukrainy 
vid 15.04.2003 r. № 114 [Methods of calculation of integral index of regional economic development, approved by the Law of the State Statistics Committee of Ukraine of 15.04.2003 № 114]. uazakon.com. http://uazakon.com/ documents/date_1a/pg_ibcnog/index.htm [in Ukrainian].

8. State Statistics Service of Ukraine (2016). Finansovi rezul'taty pidpryyemstv do opodatkuvannya za vydamy promyslovoyi diyal'nosti / Statystychna informatsiya [Financial results of enterprises before taxation by the types of industrial activities / Statistical information]. Retrieved from http://www.ukrstat.gov.ua [in Ukrainian].

9. State Statistics Service of Ukraine (2016). Pokaznyky balansu pidpryyemstv za vydamy ekonomichnoyi diyal'nosti / Ekonomichna statystyka / Ekonomichna diyal'nist' / Diyal'nist' pidpryyemstv [Balance for enterprises indicators by the types of economic activities / Economic statistics / Economic activities / Activities of enterprises]. Retrieved from http://www.ukrstat.gov.ua [in Ukrainian]. 